\title{
Joggyakorlat
}

\author{
Angyal Zoltán-KIsS LiLLA Nóra*
}

\section{Luxembourg kontra Strasbourg - Jogi akadályok az Emberi Jogok Európai Egyezményéhez való uniós csatlakozás útjában}

Emberi Jogok Európai Egyezménye - uniós csatlakozás - 2/13. sz. EUB vélemény
- alapvető jogok - egységes itélkezési gyakorlat - hatásköri kérdések

2014. december 18-án hirdette ki az Európai Unió Bírósága (a továbbiakban: Bíróság) 2/13. sz. véleményét az Európai Uniónak az emberi jogok és alapvető szabadságok védelméről szóló európai egyezményhez (a továbbiakban: EJEE) történő csatlakozásáról szóló nemzetközi megállapodás tervezetéről (a továbbiakban: megállapodás). A döntés különleges súlyát mutatja, hogy a Bíróság teljes ülésben járt el, amire a gyakorlatban rendkívül ritkán, évente mindössze egy-két ügyben kerül sor. A vélemény tartalma és indokolása határozottan rácáfolt azokra az előzetes szakmai és politikai várakozásokra, amelyek zöld jelzést prognosztizáltak, a Bíróság ugyanis úgy foglalt állást, hogy a megállapodás számos okból nem egyeztethető össze az uniós joggal. A döntés jogi akadályok sorát azonosítja, ami azt jelenti, hogy a megállapodás csak akkor léphet hatályba, ha azt módosítják, vagy ha az uniós Szerződéseket felülvizsgálják. ${ }^{1}$

Tanulmányunknak az elsődleges célja, hogy bemutassa és értékelje a megállapodás Bíróság által kifogásolt pontjait. Ezt megelőzően azonban szükségesnek látjuk, hogy röviden felvázoljuk a csatlakozás előzményeit és jogi keretét, és az elemzést követően a döntés legfontosabb rövid távú következményeit is feltárjuk. A jogi akadályok bemutatásának és értékelésének alapját kizárólag a rendkívül terjedelmes vélemény érdemi része képezte. Írásunkban - elsősorban terjedelmi korlátok miatt -

* Dr. Angyal Zoltán egyetemi docens, Miskolci Egyetem, Állam- és Jogtudományi Kar, Európajogi és Nemzetközi Magánjogi Tanszék, jogazoli@uni-miskolc.hu; Kiss Lilla Nóra ötödéves jogász szakos hallgató, Miskolci Egyetem, Állam- és Jogtudományi Kar.

1 EUMSZ 218. cikk (11) bekezdés. 
nem foglalkozunk a bírósági eljárás során a tagállamok és egyes uniós intézmények által megfogalmazott álláspontokkal, valamint nem vetettük össze a véleményt az ügyben született fötanácsnoki állásfoglalással sem. ${ }^{2}$

\section{A csatlakozás előzményei és jogi kerete}

Az emberi jogok és alapvető szabadságok védelme kiemelkedő jelentőséggel bíró kérdés a második világháború végétöl Európában. Ezen védelem kialakítása érdekében a Nyugat-Európa gazdasági értelemben véve legfejlettebb államai Londonban 1949-ben megalapították az Európa Tanácsot (a továbbiakban: ET), majd ennek keretében Rómában 1950-ben létrehozták az EJEE-t. Az eredeti végrehajtási rendszert két intézmény müködtette, az Emberi Jogok Európai Bizottsága (1954), amely eredetileg szürő szerepet töltött be, valamint a strasbourgi székhelyü Emberi Jogok Európai Bírósága (a továbbiakban: EJEB, 1959), amely a Bizottság vagy a kormányok által előterjesztett ügyekben hozott ítéleteket. ${ }^{3}$

Nem sokkal az ET megalakítása után, az ötvenes években létrejöttek az intézményesített európai integráció alapvető szervezetei, az ESZAK, az EGK és az Euratom. A három szervezet keretén belül az Európai Közösségek Bírósága kezdte meg a jogértelmező munkát luxembourgi székhellyel. A Bíróság kezdetben csupán gazdasági jellegű ügyeket tárgyalt, azonban ezen ügyeknek idővel egyre többször merült fel alapvető jogokat is érintő vetülete. Európában az alapvető jogokra vonatkozóan hármas ítélkezési gyakorlat ${ }^{4}$ alakult ki, amely sok esetben összhangban volt egymással, viszont előfordultak olyan esetek is, amikor a bíróságok eltérően értelmeztek egy-egy rendelkezést, vagy más tartalommal töltöttek meg egy jogot. ${ }^{5}$ Már 1979-ben felmerült, hogy az Európai Közösségeknek csatlakoznia kellene az EJEE-hez, amivel elméletileg egységesebb alapjogi ítélkezési gyakorlat alakulhatna ki Európában, azonban a csatlakozás mind ez idáig nem történt meg. Jelenleg 47 európai állam (köztük az Európai Unió 28 tagállama) tagja az ET-nek, és részes állama az EJEE-nek, így az új évezred elején ismét ${ }^{6}$ felvetődött az Unió EJEE-hez való csatlakozásának gondolata.

Az Európai Unió (akkori nevén: Európai Közösségek) vonatkozásában hangsúlyozandó, hogy kezdetben csupán gazdasági közösség lévén, a jogforrásai még nem

2 Lásd Juliane Kokott fötanácsnok 2014. június 13-i állásfoglalását az Európai Bizottság által kezdeményezett 2/13. számú vélemény iránti eljárásban (ECLI:EU:C:2014:2475).

3 Erröl részletesebben lásd: $h t t p: / / w w w . e u r o p a t a n a c s . h u / i n d e x . p h p ? w o r k S p a c e=p a g e s \& i d=45 \& l a n g l d=1(2015$. 01. 22.).

4 Egyrészt a Bíróság általi, másrészt az EJEB általi, harmadrészt a tagállami bíróságok általi jogértelmezés.

5 A 11/70. számú. Internationale Handelsgesellschaft mbH kontra Einfuhr- und Vorratsstelle für Getreide und Futtermittel ügyben (ECLI:EU:C:1970:114) például a frankfurti közigazgatási bíróság került szembe azzal a problémával, hogy a közösségi jogszabályok által az exportengedélyek kiadásához megkövetelt biztosítékrendszer szembement a német Alaptörvény gazdasági szabadságra vonatkozó, alapjogi előírásaival. A közösségi jog elsöbbsége az alkotmányos alapjogok alkalmazásától való eltekintést követelte volna meg. Az eset tehát az Európai Bíróság és a német alkotmánybíróság, illetve az elsőbbség elvének és az alapjogok védelmének a szembenállását jelentette.

6 Az 1990-es években megindított csatlakozási folyamatokat, és ide kapcsolódóan a Bíróság 2/94. számú véleményét követően. 
tartalmaztak kifejezetten alapjogi rendelkezéseket. ${ }^{7}$ A Bíróság azonban egyre többször szembesült olyan esetekkel, amelyek az emberi jogokat is érintették. ${ }^{8}$ A Bíróságnak a következetesség érdekében általános elveket kellett kidolgoznia ezen ügyek rendezésére. Ezek közé tartozik például, hogy az alapjogok az Unió általános jogelveinek részét képezik, ${ }^{9}$ valamint az, hogy az alapjogok tartalmát a tagállamok közös alkotmányos hagyományai alkotják. ${ }^{10}$ A Bíróság alapjogi joggyakorlatának kialakulásában harmadik lépést jelentett a Nold-ügyben ${ }^{11}$ hozott ítélet indoklása, melyben található „az első, általános, nem nevesített utalás a nemzetközi emberi jogi egyezményekre, melyeknek a tagállamok az aláírói és melyek követendő iránymutatást adnak a közösségi jogban is". ${ }^{12}$ A Rutili-ügyben ${ }^{13}$ már nevesíti is a Bíróság az EJEE-t, amikor egyes emberi jogok korlátozására vonatkozó rendelkezéseire hivatkozik. A Hauer-ügyben ${ }^{14}$ a Bíróság először elemzi az EJEE egy konkrét cikkét, hogy megállapítsa egy alapjog - nevezetesen a tulajdonhoz való jog - tartalmát. ${ }^{15}$ Később, 1989-ben pedig a Bíróság első alkalommal hivatkozott az ENSZ Emberi Jogi Egyezményére, az 1966-os Polgári és Politikai Jogok Nemzetközi Egyezségokmányára, az Orkem-ügyben. ${ }^{16}$ Látható, hogy a Bíróság uniós emberi jogi dokumentum hiányában támaszkodott a már létező dokumentumokra, mechanizmusokra. ${ }^{17}$ A folyamatok és a Bíróság ítélkezési gyakorlatának következményeként 1986-ra az alapjogok védelme bekerült az Egységes Európai Okmány által módosított EGK Szerződés preambulumába. Azonban az alapjogvédelem akkor még csak általános célkitűzésként jelent meg, bizonyos generálklauzulák formájában, a jogok tartalmának meghatározása nélkül. ${ }^{18}$

Az akkori Európai Közösség ezt követően válaszút elé került: az egyik megoldás, hogy összeállítja az alapjogok katalógusát egy kötelező uniós jogi aktusban, a másik megoldás pedig az, hogy a Közösség maga is csatlakozik az EJEE-hez. A csatlakozással kapcsolatban azonban a Bíróság a 2/94. számú véleményében

7 Az Európai Uniót alapító szerződések csak szórványosan rendelkeztek az emberi jogokról, például a nem alapján történő hátrányos megkülönböztetés tilalmát előíró rendelkezés (EGK Szerződés 119. cikke, jelenleg EUMSZ 157. cikk), valamint az állampolgárság alapján történő hátrányos megkülönböztetés tilalma (EGK Szerződés 7. cikk, jelenleg EUMSZ 18. cikk).

8 Kezdetben - mivel az alapjogvédelem jogalapja nem szerepelt expressis verbis az alapító Szerződésekben - az EUB hatáskör hiányában többször is elutasította az emberi jogok megsértésére alapozott kereseteket. PI.: 1/58. számú, Stork-ügy (ECLI:EU:C:1959:4), 40/64. számú, Sgarlata-ügy (ECLI:EU:C:1965:36).

9 Ezt a Bíróság 1969-ben a 29/69. számú, Erich Stauder kontra Stadt Ulm - Sozialamt ügyben mondta ki először (ECLI:EU:C:1969:57), 7. pont.

10 Ezt a 11/70. számú. Internationale Handelsgesellschaft ügyben mondta ki a Bíróság (ECLI:EU:C:1970:114), 4. pont.

11 4/73. számú, J. Nold, Kohlen- und Baustoffgrosshandlung kontra Bizottság ügy (ECLI:EU:C:1974:51) 13. pont.

12 Blutman László: Az Európai Unió joga a gyakorlatban, HVG-ORAC, Budapest, 2010, 477.

13 36/75. számú, Roland Rutili kontra Ministre de l'intérieur ügy (ECLI:EU:C:1975:137), 32. pont.

14 44/79. számú, L. Hauer kontra Land Rheinland-Pfalz ügy (ECLI:EU:C:1979:290) 17-19. pontok.

15 Az ügy tényállása szerint a közösségi jogszabály korlátot állított fel új szőlőültetvény telepítésére, Hauer pedig a tulajdonjogának mint alapvető emberi jogának közösségi jogi korlátozására hivatkozott.

16 374/87. számú, Orkem kontra Bizottság ügy (ECLI:EU:C:1989:387) 31. pont.

17 Vagy épp „hívják segítségül” egymás gyakorlatát az eredményesség érdekében, erre lásd, pl: C-254/99. számú, P Limburge Vinyl Maatschappij NV (LVM) és mások kontra Bizottság ügy (ECLI:EU:C:2002:582).

18 A jogok tartalmát, terjedelmét az egyes bírósági döntések határozták meg. 
(1996) ${ }^{19}$ egyértelmüen kifejtette, hogy „az alapitó szerződések keretében nincs hatásköre az Uniónak a csatlakozásra, és a csatlakozás alapvetően megváltoztatná az Unió jogrendjét és jogi konstrukcióját”. ${ }^{20}$ 1996-ban még nem volt elvileg sem öszszeegyeztethető a csatlakozás az EK Szerződéssel, hiszen hiányzott az a jogalap és célkitűzés, amelyeket majd csak a Lisszaboni Szerződés teremtett meg. Továbbá „1996-ban a csatlakozás kereteinek jogi elökészítése volt az, ami komoly hiányosságokban szenvedett. A legnagyobb hiányosságokat maga a Bíróság nevesítette, többek között, hogy a csatlakozás nem veszi figyelembe az EUB által kimunkált doktrínákat, elveket. [...] Az EUB szerint a csatlakozási dokumentumok nem tartalmaztak kifejezetten védő jellegü rendelkezéseket az uniós jog autonómiájára és jellegére nézve". ${ }^{21}$

A hézag kitöltésére az Európai Parlament, az Európai Unió Tanácsa és a Bizottság 2000-ben kihirdette az Európai Unió Alapjogi Chartáját, mely a Lisszaboni Szerződés hatálybalépéséig (2009 decemberéig) mint „politikai nyilatkozat” létezett, jogi kötőerő nélkül. ${ }^{22}$

A Charta létrehozásától függetlenül a későbbiekben mégis felmerült az Unió EJEE-hez történő csatlakozásának igénye. Ehhez a célkitűzést és a hiányzó jogalapot a Lisszaboni Szerződés által módosított EUSZ teremtette meg expressis verbis 6. cikkének (2) bekezdésével, mely kimondja, hogy „[a]z Unió csatlakozik az emberi jogok és alapvető szabadságok védelméről szóló európai egyezményhez". ${ }^{23}$ E tekintetben az Uniónak az EJEE-hez történő csatlakozásról szóló, 8. sz. Jegyzökönyv ${ }^{24}$ úgy rendelkezik, hogy a csatlakozásra irányuló megállapodásnak meg kell felelnie bizonyos feltételeknek, így különösen rendelkeznie kell az Unió és az uniós jog sajátos jellemzőinek megőrzéséröl, valamint biztosítania kell, hogy a csatlakozás nem érinti sem az Unió, sem az Unió intézményeinek hatásköreit. A csatlakozás lehetőségét az EJEE tekintetében az ellenőrző rendszer módosítására vonatkozó, tizennegyedik jegyzőkönyv ${ }^{25}$ teremtette meg, mely módosítva az EJEE 59. cikkét, kimondja, hogy „[a]z Európai Unió csatlakozhat az Egyezményhez”.

19 A Bíróság 2/94. számú véleménye, melyet a Tanács kérelmezett az (akkor még) EK-Szerződés 228. cikkének (6) bekezdése alapján. A Tanács abban a kérdésben kérte a Bíróság véleményét, hogy az Európai Közösség csatlakozása az emberi jogok és alapvető szabadságok védelméröl szóló egyezményhez összeegyeztethető-e az Európai Közösséget létrehozó szerződéssel (ECLI:EU:C:1996:140).

20 Blutman: i. m., 481.

21 VARJU, Márton: Keeping separate what belongs together? Opinion 2/13 of the EU Court of Justice on the accession of the European Union to the European Convention on Human Rights. http://hpops.tk.mta.hu/en/ blog/2015/02/keeping-separate-what-belongs-together (2015. 03. 01.).

22 Az EUSZ Lisszaboni Szerződés által módosított 6. cikk (1) bekezdése ruházta fel jogi kötőerővel a Chartát, méghozzá ugyanolyannal, mint amilyennel a Szerződések rendelkeznek.

23 EUSZ 6. cikk (2) bekezdés.

24 (8.) Jegyzőkönyv Az Európai Unióról Szóló Szerződés 6. cikkének (2) bekezdésével összefüggésben az Uniónak az Emberi Jogok és Alapvető Szabadságok Védelméröl Szóló Európai Egyezményhez történő csatlakozásáról.

25 Az EJEE-nek az egyezmény ellenőrző rendszerének módosítására vonatkozó tizennegyedik jegyzőkönyve, amelyet 2004. május 13-án fogadtak el, és amely 2010. június 1-jén lépett hatályba (Magyarországon kihirdette a 2005. évi CXXIV. törvény). 
A csatlakozás tehát nem érintheti az Unió Szerződésekben meghatározott hatásköreit, sem pedig az intézményei hatásköreit, sőt a csatlakozást követően is az EUnak és az uniós jognak meg kell őriznie sajátosságait. Azonban az uniós jog külső kontroll alá helyezése, egy független bírósági testület általi felülvizsgálatának a lehetősége már önmagában megkérdőjelezi az autonómia biztosíthatóságát. A csatlakozással az EJEE az uniós jog szerves részét képezné, így kötelező erővel kötné az uniós intézményeket is. Ez felvetné az uniós jog alapjaiban történő megváltozásának következményét. A másik vonzata a csatlakozásnak az uniós jog értelmezéséhez kapcsolódik, hiszen az interpretáció jelenleg a Bíróság kizárólagos hatáskörébe ${ }^{26}$ tartozik az EUMSZ értelmében, csakúgy, mint egy uniós aktus érvénytelenné ${ }^{27}$ nyilvánítása. ${ }^{28}$ Viszont a csatlakozással az uniós jog kerülne külső kontroll alá, így elvben két fórum is jogosult lenne az ítélkezésre, a Bíróság és az EJEB. Ha pedig az EJEB adott esetben felülvizsgálhatná a Bíróság által hozott döntéseket, ezzel a Bíróság eddigi kizárólagos hatásköre automatikusan kvázi „korlátozott” hatáskörré alakulna át. Ez egyértelmüen csorbítaná a Bíróság hatásköreit, és ennélfogva megváltoztathatná az uniós jog jellegét. Ez ellentmondana a Bíróság Kadi-ügyben ${ }^{29}$ megfogalmazott elvárásának, amely szerint egy nemzetközi szerződésnek nem lehet kedvezőtlen hatása a közösségi jogrendszer autonómiájára nézve.

A Bizottság 2010. március 17-i ajánlását követően a Tanács 2010. június 4-én határozatot fogadott el, amelyben felhatalmazást adott a csatlakozásra irányuló megállapodásról szóló tárgyalások megkezdésére, és a Bizottságot jelölte ki tárgyaló félként. A tárgyalások eredményeképpen 2013. április 5-én a tárgyaló felek között megállapodás jött létre a csatlakozási dokumentumok tervezeteire vonatkozóan. ${ }^{30}$ A Bizottság 2013. július 4-én az EUMSZ 218. cikk (11) bekezdése alapján vélemény iránti kérelmet terjesztett elő a Bírósághoz, amelyben arra a kérdésre várt választ, hogy vajon összeegyeztethető-e a Szerződésekkel az Uniónak az EJEE-hez történő csatlakozására irányuló megállapodás.

${ }^{26}$ Az uniós jog értelmezésére, az egységes értelmezés biztosítására az előzetes döntéshozatali eljárás szolgál, melynek jogi kereteit az EUMSZ 267. cikke tartalmazza, általános hatáskört biztosítva az EUSZ 19. cikk (3) bekezdés b) pontjával összhangban a Bíróság számára. Az EU jogának értelmezése mellett az uniós intézmények, szervek vagy hivatalok jogi aktusainak érvényességére vonatkozó előzetes döntést is meghozza. Erről részletesebben lásd: AngYal Zoltán-AsztALos Zsófia-FAZEKAS Judit-Gyeney Laura-MetZINGER Péter-Milassin László-Osztovits András-Szabó Marcel: EU-jog, HVG-ORAC, Budapest, 2012, 314-337.

$27 \mathrm{Ha}$ az érvénytelenné nyilvánításra, vagy az értelmezésre a nemzeti bíróságoknak is lenne hatásköre, akkor az eltérő vélemények rendszertelen, egység nélküli uniós jogrendszerhez vezetnének. Erre a Bíróság többek között a C-314/85. számú, Foto-Frost ügyben (ECLI:EU:C:1987:452) is rámutatott.

28 Ezt már a Bíróságnak „Az Uniónak az EJEE-hez való csatlakozásával kapcsolatban” született vitairata (2010) is tartalmazta.

29 Az Európai Bíróság C-402/05. P. és C-415/05. P. számú, Y. A. Kadi és Al Barakaat International Foundation kontra az Európai Unió Tanácsa és az Európai Bizottság egyesített ügyekben hozott határozata (ECLI:EU:C:2008:461).

30 A csatlakozási tárgyalások jogszerüségéröl, nyilvánosságának kérdéséről indított perről lásd: T-331/11. számú, Leonard Besselink kontra az Európai Unió Tanácsa ügy (ECLI:EU:T:2013:419), „Access to documents case”. 


\section{A Bíróság véleményének föbb megállapításai}

A Bíróság a véleményében egyértelműen nemleges választ adott a Bizottság kérdésére, azaz úgy vélte, hogy az EU-nak az EJEE-hez történő csatlakozásra irányuló megállapodása számos okból nem egyeztethetö össze az EUSZ 6. cikk (2) bekezdésével, valamint az Uniónak az EJEE-hez történő csatlakozásáról szóló 8. sz. jegyzőkönyvével.

A vélemény érdemi részének bevezetéseként a Bíróság részletes okfejtést adott az Unió és az uniós jog sajátos jellemzőiröl, valamint arról, hogy ezek miként befolyásolják az EJEE-hez tervezett uniós csatlakozást. A Bíróság szerint nem lehet figyelmen kívül hagyni azt a tényt, hogy az EJEE elfogadása óta kizárólag államok lehettek annak részesei, és jelenleg is kizárólag államokra kötelező. ${ }^{31}$ Ezzel szemben az Unió nemzetközi jogi értelemben „a természeténél fogva nem tekinthető államnak". ${ }^{32}$ A vélemény részletes indokolásának kiindulópontjaként az a sokat idézett fordulat szolgál, amely szerint az Unió új, különleges jogrenddel, saját alkotmányos kerettel és alapelvekkel, önálló intézményi berendezkedéssel, valamint ezek müködését biztosító jogrendszerrel rendelkezik.

Azon az elvi szintủ felvetésen túl, hogy az uniós jogrend autonóm és sajátos, az uniós jognak három - ezt a felvetést kifejezésre juttató - rendelkezése képezte a Bíróság jogi érvelésének alapját. Az első az EUSZ 6. cikk (2) bekezdése, amely kimondja, hogy az Unió csatlakozik az EJEE-hez, azonban „a csatlakozás nem érinti az Uniónak a Szerződésekben meghatározott hatásköreit". A második a 8. sz. EUjegyzőkönyv, amely egyebek mellett elöŕrja, hogy a csatlakozási megállapodásnak rendelkeznie kell az Unió és az uniós jog sajátos jellemzőinek megőrzéséről, és biztosítania kell, hogy a csatlakozás nem érinti sem az Unió, sem az Unió intézményeinek hatásköreit, sem pedig a tagállamoknak az EJEE-vel kapcsolatos helyzetét, és az EUMSZ 344. cikkét sem. A harmadik egy jogi kötelező erővel ugyan nem rendelkező, de az értelmezéshez felhasználható nyilatkozat, amely szerint az Unió csatlakozására az uniós jog sajátosságainak megőrzése mellett kell hogy sor kerüljön. ${ }^{33}$

A tervezett megállapodásnak az elsődleges uniós joggal való összevetése során a Bíróság egyfelől azt vizsgálta, hogy a megállapodás valamely része sértheti-e az uniós jog sajátos jellemzőit és autonómiáját, másfelöl hogy a megállapodásban lefektetett intézményi és eljárási mechanizmusok eleget tesznek-e azon feltételeknek, amelyekben a Szerződések az egyezményhez való uniós csatlakozást kötik. A véleményben a bírák hét problémás területet azonosítottak, amelyeken a tervezett megállapodás további kiegészítésre vagy módosításra szorul annak érdekében, hogy az ne érintse, illetve sértse az Unió és az uniós jog sajátos jellemzőit.

31 Ez a magyarázata annak is, hogy az Unió csatlakozásához szükség volt egyrészt az EJEE 59. cikkének módosítására, másrészt a tervezett megállapodásban is számos, az egyezményt érintő módosítás található. Utóbbiakra azért volt szükség, hogy az Unió csatlakozása működőképes legyen az eredetileg kizárólag államok számára kidolgozott rendszerben.

32 Lásd a vélemény 156. pontját.

33 Lásd a Lisszaboni Szerződést elfogadó kormányközi konferencia zárónyilatkozatához csatolt 2. sz. nyilatkozatot az EUSZ 6. cikkének (2) bekezdéséröl. 
2.1. Elsőként a Bíróság azt kifogásolta, hogy az egyezmény nem tartalmaz rendelkezéseket az EJEE 53. cikke és a Charta 53. cikke közötti összhang biztosítására. A csatlakozással ugyanis az EJEE kötné az uniós intézményeket és a tagállamokat, így az uniós jog szerves részévé válna. ${ }^{34}$ A Bíróság szerint ez azzal a következménynyel járna, hogy az Unió külső ellenőrzés alá kerülne az általa az egyezményben vállalt jogok és kötelezettségek tiszteletben tartása tekintetében. A külső ellenőrzés azt is jelentené, hogy az Unió és annak összes intézménye, a Bírósággal együtt, az EJEE-ben foglalt ellenőrzési mechanizmus és az EJEB határozatai alá lennének rendelve. ${ }^{35}$ Fontos megjegyezni azt, hogy a Bíróság - hivatkozva saját korábbi gyakorlatára - nem zárta ki az elvi lehetőségét egy ehhez hasonló külső ellenőrzésnek, amennyiben azt a Szerződések írják elő. Ami közelebbről a Bíróság külső kontrollját illeti, korábbi ügyekben a luxembourgi bírák már úgy foglaltak állást, hogy egy nemzetközi megállapodásnak csak akkor lehet hatása a Bíróság hatáskörére, ha az e hatáskör megőrzésére vonatkozó feltételek teljesülnek, és így nem sérül az uniós jogrend autonómiája. ${ }^{36} \mathrm{~A}$ Bíróság - megerősítve egy korábbi véleményében kifejtett álláspontját - úgy vélte, hogy a szóban forgó ellenőrzési mechanizmus, beleértve az EJEB müködését, nem járhat azzal a hatással, hogy az Uniót és annak intézményeit a belső hatásköreik gyakorlása során az uniós jog szabályainak sajátos értelmezésére kötelezi. ${ }^{37} \mathrm{~A}$ külső ellenőrzés a Bíróság értelmezésében azt jelentené, hogy egyrészt az EJEE-nek az EJEB általi értelmezése kötné az Uniót és az intézményeit, beleértve a Bíróságot, másrészt az EJEE-ben foglalt valamely jog Bíróság általi értelmezése nem kötné az említett ellenőrzési mechanizmusokat, és különösen az EJEB-et. Új elemként jelenik meg a véleményben, hogy a külső ellenőrzésnek ez a következménye nem lehet érvényes azon értelmezésre, ahogyan a Bíróság az uniós jogot, beleértve a Chartát, értelmezi. A Bíróság azt is határozottan leszögezte, hogy az EJEB nem vitathatja a Bíróságnak azon döntéseit, amelyekben megállapítja, hogy valamely tagállam köteles-e tiszteletben tartani az alapvető uniós jogokat. ${ }^{38}$

Az EJEE és a Charta említett szakaszai közötti ellentmondást a következőkben látta a Bíróság. A Charta 53. cikke előírja, hogy annak egyetlen rendelkezését sem lehet úgy értelmezni, mint amely szükíti vagy hátrányosan érinti azokat az alapvető jogokat, amelyeket - saját alkalmazási területükön - az Unió joga, a nemzetközi jog, a tagállamok alkotmányai, illetve az Unió vagy a tagállamok mindegyikének részességével kötött nemzetközi megállapodások, így különösen az EJEE elismernek. A Bíróság korábban úgy értelmezte ezt a rendelkezést, hogy az alapvető jogok nemzeti védelmi szintjeinek alkalmazása nem veszélyeztetheti a Charta által meghatározott védelmi szintet, sem pedig az uniós jog elsőbbségét, egységességét és hatékonyságát. ${ }^{39}$ A Bíróság szerint, mivel az EJEE 53. cikke lényegében fenntartja

34 Lásd ehhez még az EUMSZ 216. cikk (2) bekezdését.

35 Lásd a vélemény 180-181. pontjait.

36 Lásd ehhez az 1/00. számú vélemény (ECLI:EU:C:2002:231) 21., 23. és 26. pontjait; valamint az 1/09. számú vélemény (ECLI:EU:C:2011:123) 76. pontját.

37 Lásd ehhez az 1/91. számú vélemény (ECLI:EU:C:1991:490) 30-35. pontját; valamint az 1/00. számú vélemény (ECLI:EU:C:2002:231) 13. pontját.

38 Lásd a vélemény 186. pontját.

39 Lásd a C-399/11. számú, Melloni-ügyben született ítélet (ECLI:EU:C:2013:107) 60. pontját. 
a lehetőséget a szerződő felek számára, hogy az alapvető jogok magasabb védelmi szintjét írják elő, mint amelyet az EJEE biztosít, biztosítani kell e rendelkezés és a Chartának a Bíróság által értelmezett 53. cikke közötti összhangot. A Bíróság érvelésében erre azért van szükség, hogy az EJEE 53. cikkében a tagállamok számára biztosított lehetőség a Chartában elismert azon jogok tekintetében, amelyek megfelelnek az említett egyezményben biztosított jogoknak, olyan szintre korlátozódjon, amely a Chartában foglalt védelmi szint, valamint az uniós jog elsőbbsége, egységessége és hatékonysága veszélyeztetésének elkerüléséhez szükséges.

2.2. Másodikként a Bíróság a tagállamok közötti kölcsönös bizalom elve, és annak értelmezése felöl közelítette meg a tervezett megállapodást. A Bíróság értelmezésében ennek az elvnek alapvető jelentősége van az uniós jogban, különösen a szabadságon, a biztonságon és a jog érvényesülésén alapuló területeken. Az elv röviden azt jelenti, hogy mindegyik tagállam köteles - kivételes körülményektöl eltekintve - úgy tekintetni, hogy az összes többi tagállam tiszteletben tartja az uniós jogot, és különösen az uniós jog által elismert alapvető jogokat. ${ }^{40} \mathrm{~A}$ véleményben a Bíróság tovább pontosította a kölcsönös bizalom elvének jelentését. Eszerint egyrészt nem lehetséges az, hogy valamely tagállam egy másik tagállamtól az alapvető jogok uniós jog által biztosított védelmi szintjénél magasabb védelmi szintet követeljen meg. Másrészt, egyetlen tagállam sem vizsgálhatja, hogy egy másik tagállam egy konkrét ügyben tiszteletben tartotta-e az Unió által biztosított alapvető jogokat. ${ }^{41}$ A Bíróság szerint e tekintetben mindenképpen hibás a megállapodásban alkalmazott azon megközelítésmód, amely az Uniót egy államhoz hasonlítja, és az összes más szerződő fél szerepével minden tekintetben megegyező szerepet szán neki. A Bíróság megfogalmazásában azért hiba az Uniót a többi szerződő állammal együtt kezelni, mert ezzel „pontosan az Unió önmagában rejlő jellegét nem veszi figyelembe”, és figyelmen kívül hagyja azt, hogy - azokon a területeken, ahol az Unióra hatásköröket ruháztak - a tagállamok közötti „kapcsolatokat az uniós jog szabályozza, kizárva - ha az uniós jog ezt követeli meg - minden más jogot”. ${ }^{42}$ A Bíróság ellentmondást fedezett fel abban, hogy miközben az uniós jog a kölcsönös bizalmat írja elő a tagállamok között, addig az EJEE megkövetelné a tagállamoktól, hogy adott esetben vizsgálják meg az alapvető jogok más tagállam általi tiszteletben tartását. A vélemény szerint mivel a megállapodás semmit nem ír elő ezen ellentmondás elkerülése érdekében, a változatlan tartalommal való hatálybalépése esetén a csatlakozás alkalmas lenne az Unió alapjául szolgáló egyensúly, valamint az uniós jog autonómiájának veszélyeztetésére.

2.3. Harmadikként a Bíróság az EJEE-hez csatolt tizenhatodik jegyzőkönyvvel foglalkozott, amelyet 2013. október 2-án írtak alá, vagyis azt követően, hogy 2013 áprilisában létrejött az e vélemény által megvizsgált megállapodás a tárgyaló felek

40 Lásd ebben az értelemben a C-411/10. és C-493/10. számú, N. S. és társai itélet (ECLI:EU:C:2011:865) 78-80. pontját.

41 Lásd a vélemény 192. pontját.

42 Lásd a vélemény 193. pontját. 
között. E jegyzőkönyv lehetővé teszi a tagállamok legmagasabb szintű bíróságai számára, hogy tanácsadó vélemény iránti kérelmet intézzenek az EJEB-hez az EJEE-ben vagy az ahhoz csatolt jegyzőkönyvekben biztosított jogok és szabadságok értelmezésével vagy alkalmazásával kapcsolatos elvi kérdésekre vonatkozóan. A Bíróság szerint ez az opció azért problémás, mert az uniós jog megköveteli, hogy e célból ugyanezen tagállami bíróságok a Bírósághoz nyújtsanak be előzetes döntéshozatal iránti kérelmet az EUMSZ 267. cikk alapján. A Bíróság is elismerte, hogy a tervezett megállapodás maga nem írja elő az Unió csatlakozását ehhez a jegyzökönyvhöz, és hogy az idöben később is született meg, ugyanakkor úgy vélte, hogy amennyiben az EJEE az uniós jog szerves részét képezné, akkor a szóban forgó jegyzőkönyvvel létrehozott mechanizmus érinthetné az előzetes döntéshozatali eljárás autonómiáját és hatékonyságát. A vélemény erre azt a konkrét példát hozza fel, hogy a jegyzőkönyv alapján valamely, a jegyzőkönyvhöz csatlakozott tagállam bírósága által benyújtott tanácsadó vélemény iránti kérelem alapján megindulhatna a Bíróság előzetes bevonására irányuló eljárás. Ez utóbbi pedig „az elózetes döntéshozatali eljárás megkerülésének veszélyét idézné elö, amely [...] a Szerződések által létrehozott bírósági rendszer sarokkövének minősül". ${ }^{43}$ A Bíróság konklúziója, hogy a tervezett megállapodás - mivel nem tartalmaz semmilyen elöírást az EJEBhez intézendő tanácsadó vélemény iránti kérelem és a Bíróság előzetes döntéshozatali eljárás viszonyára vonatkozóan - alkalmas arra, hogy megsértse az utóbbi eljárás hatékonyságát és autonómiáját.

2.4. Negyedikként a Bíróság az EUMSZ 344. cikkét vetette össze a megállapodással. A 8. sz. EU-jegyzőkönyv kifejezetten előírja, hogy a csatlakozási megállapodás nem érinti az EUMSZ 344. cikket. Az elsődleges uniós jog e szabálya kimondja, hogy a tagállamok vállalják, hogy a Szerződések értelmezésére vagy alkalmazására vonatkozó vitáikat kizárólag a Szerződésekben előírt eljárások útján rendezik. A Bíróság álláspontja szerint a tagállamoknak ezt a kötelezettségét az uniós jog egyik alapelvének tekintendő lojális együttmüködési kötelezettség ${ }^{44}$ sajátos megnyilvánulásaként kell érteni, vagyis az a tagállamok és az Unió közötti kölcsönös viszonyokban is alkalmazandó. ${ }^{45} \mathrm{~A}$ vélemény alapján ebböl az is következik, hogy miután az EJEE az uniós jog szerves részévé válna, amennyiben az uniós jog érintett, akkor a Bíróságnak van kizárólagos hatásköre minden, a tagállamok közötti, illetve a tagállamok és az Unió közötti, az EJEE tiszteletben tartásának tárgyában indult jogvita elbírálására. A megállapodás 5 . cikke ugyan elöírja, hogy a Bíróság előtti eljárások nem minősülnek olyan vitarendezési módnak, amelyről a szerződő felek az EJEE 55. cikke értelmében lemondtak, a Bíróság szerint ez önmagában nem elegendő a Bíróság kizárólagos hatáskörének megörzéséhez. A vélemény ezt azzal támasztja alá, hogy az említett 5 . cikk ellenére a megállapodás fenntartja azt a lehetőséget, hogy az Unió vagy a tagállamok az EJEE 33. cikke alapján az EJEB-hez fordulhassanak egy olyan kérelemmel, amelynek tárgya az EJEE-nek az Unió, illetve vala-

\footnotetext{
43 Lásd a vélemény 198. pontját.

44 EUSZ 4. cikk (3) bekezdés.

45 Lásd a vélemény 202. pontját.
} 
mely tagállam általi, az uniós joggal kapcsolatos állítólagos megsértése. A Bíróság rendkívül erősen fogalmaz erröl, amikor megállapítja, hogy „az ilyen lehetőségnek még a létezése is sérti az EUMSZ 344. cikkben foglalt követelményt", ${ }^{46}$ mivel ellentétes az uniós jog jellegével, amely elöírja, hogy a tagállamok közötti viszonyokat az uniós jog szabályozza, kizárva - ha az uniós jog ezt követeli meg - minden más jogot. A Bíróság szerint a megállapodás csak akkor lenne összeegyeztethető az EUMSZ 344. cikkel, ha kifejezetten kizárná az EJEB-nek az EJEE 33. cikkből eredő hatáskörét a tagállamok, valamint a tagállamok és az Unió közötti, az EJEE-nek az uniós jog tárgyi hatálya alá tartozó alkalmazásával kapcsolatos jogviták vonatkozásában.

2.5. Ötödikként a Bíróság az ún. alperesi pertársaság mechanizmusának részletszabályait elemezte. Az alperesi pertársaság mechanizmusát az EJEE rendszerében az olyan joghézagok elkerülése érdekében vezették be, amelyek az Uniónak - mint sajátos szerződő félnek - az egyezményhez való csatlakozásából eredhetnek. ${ }^{47} \mathrm{~A}$ mechanizmusnak továbbá az a célja, hogy a nem tagállamok által benyújtott kérelmek és az egyéni kérelmek helyesen a tagállamok, illetve adott esetben az Unió ellen irányuljanak. A Bíróság megvizsgálta, hogy vajon e célkitüzéseknek a megállapodásban történő megvalósítása összeegyeztethető-e az uniós joggal. A vizsgálat eredményeképpen három területen jelez problémát a vélemény.

A megállapodás elöírja, hogy egy szerződő fél két módon válhat alperesi pertárssá. Egyrészt az EJEB felhívásának elfogadásával, másrészt az EJEB-nek a szerződő fél kérelmére hozott határozatával. Amikor az EJEB felhívna egy szerződő felet, hogy legyen alperesi pertárs, e felhívás nem kötelezö, vagyis az Uniónak és a tagállamoknak szabadon kell mérlegelniük, hogy teljesülnek-e a mechanizmus alkalmazásának anyagi feltételei, amely mérlegelés szükségszerüen az uniós jog értékelését feltételezi. A Bíróság a másik esetet tartotta problémásnak, azaz amikor egy szerződő fél erre irányuló kérelmére kell határoznia az EJEB-nek a mechanizmusról. A megállapodás értelmében ilyenkor a kérelmezőknek - az Uniónak vagy a tagállamoknak - elö kell adniuk azon bizonyítékaikat és érveiket, hogy az eljárásban való részvételükre vonatkozó feltételek teljesülnek. A Bíróság úgy vélte, hogy ilyen esetben az EJEB-nek a határozata meghozatala során alapvetően az uniós jog azon szabályait kellene értékelnie, amelyek az uniós jognak az Unió és a tagállamai közötti hatáskörmegosztásra, valamint az Unió vagy a tagállamok aktusainak vagy mulasztásainak betudhatósági szempontjaira vonatkoznak. A Bíróság szerint az EJEB ilyen ellenőrzése „alkalmas arra, hogy megzavarja az Unió és a tagállamai közötti hatáskörmegosztást". 48

A második észrevétel a megállapodás azon szakaszával volt kapcsolatos, amely szerint, ha a jogsértés, amelyhez kapcsolódóan a szerződő fél egy eljárásban alperesi pertársként részt vesz, megállapítást nyer, az alperes és az alperesi pertárs

46 Lásd a vélemény 208. pontját.

47 Lásd bővebben a megállapodáshoz kapcsolódó magyarázó jelentés tervezetének 39. pontját.

48 Lásd a vélemény 222-225. pontját. 
együttesen felel e jogsértésért. ${ }^{49} \mathrm{~A}$ Bíróság szerint így elöállhatna olyan helyzet, hogy valamely tagállamot az Unióval együttesen lehessen felelőssé tenni az EJEE olyan rendelkezésének megsértéséért, amely tekintetben ugyanezen tagállam fenntartást tett. ${ }^{50} \mathrm{~A}$ Bíróság ezért úgy vélte, hogy ez a lehetőség sérti a 8 . EU-jegyzőkönyv 2. cikkét, amely szerint a megállapodásnak biztosítania kell, hogy az ne befolyásolhassa a tagállamoknak az EJEE-vel, és különösen az arra vonatkozóan tett fenntartásokkal kapcsolatos helyzetét.

A harmadik kritikus pontnak a megállapodás azon pontja bizonyult, amely eltérést enged attól az általános szabálytól, mely szerint az alperes és az alperesi pertárs együttesen felel a megállapított jogsértésért. ${ }^{51} \mathrm{Az}$ EJEB az alperes, a pertárs és a kérelmező meghallgatását követően dönthet úgy, hogy közülük csak az egyikük felel a jogsértésért. A Bíróság szerint az EJEB olyan tárgyú határozatának meghozatalához, amely rendelkezik az EJEE megsértésének minősülő jogi aktus vagy mulasztás alapján fennálló felelősség az Unió és tagállamai közötti megosztásáról, szintén az uniós jog azon szabályainak értékelése szükséges, amely előidézheti az Unió és a tagállamai közötti hatáskörmegosztás megsértését.

2.6. Hatodikként a vélemény a Bíróság előzetes bevonására irányuló eljárásának részletszabályaival foglalkozott. Az EJEB előtt folyamatban lévő olyan eljárásba, amelyben az uniós jog is érintett, a megállapodás lehetővé teszi a Bíróság előzetes bevonására irányuló eljárás alkalmazását. Az eljárást az uniós bírák két ponton is kifogásolták.

Egyfelöl a Bíróság szerint az eljárásnak az lenne a célja, hogy azon kérdést, hogy a Bíróságnak van-e már precedens értékű döntése az EJEB előtti eljárás tárgyát képező jogkérdésröl, csak uniós intézmény válaszolhassa meg, és a döntés legyen kötelező az EJEB-re nézve. Ezzel szemben a véleményben a Bíróság azt állapította meg, hogy a megállapodás nem zárja ki annak a lehetőségét, hogy az EJEB is határozhasson ilyen kérdésröl, ami azonban a Bíróság ítélkezési gyakorlatának értelmezésére vonatkozó hatáskör gyakorlását jelentené. Ebböl azt a következtetést vonta le, hogy az előzetes bevonásra irányuló eljárást úgy kellene kialakítani, hogy az EJEB előtti minden folyamatban lévő ügyben megfelelő információkat kapjon az Unió ahhoz, hogy a hatáskörrel rendelkező uniós intézmény képes legyen mérlegelni és dönteni abban a kérdésben, hogy a Bíróság foglalt-e már állást hasonló kérdésről, és ha nem, akkor elérje ezen eljárás alkalmazását.

A másik kifogás azzal volt kapcsolatos, hogy az előzetes bevonásra irányuló eljárásban a Bíróság megvizsgálhatja az érintett uniós jogi rendelkezéseknek az EJEEben vagy az Unió által aláírt jegyzőkönyvekben foglalt jogokkal való összeegyeztethetőségét. A Bíróság ezzel összefüggésben a magyarázó jelentés tervezetének azon megállapításával nem ért egyet, amely szerint „a rendelkezés összeegyeztethetőségének vizsgálata" kifejezés alapvetően a másodlagos uniós jog valamely rendelkezésének érvényességére, vagy az elsődleges jog valamely rendelkezésé-

\footnotetext{
49 Lásd a megállapodás 3. cikkének (7) bekezdését.

Az EJEE 57. cikke alapján.

51 Lásd a megállapodás 3 . cikkének (7) bekezdését.
} 
nek értelmezésére vonatkozó döntést jelenti. ${ }^{52} \mathrm{~A}$ Bíróság ebböl azt a következtetést vonta le, hogy a megállapodás kizárja a másodlagos jog értelmezésére vonatkozó kérdéseket, holott erre adott esetben szükség lehet annak eldöntéséhez, hogy az adott jogi aktus megfelel-e az Unió EJEE-hez való csatlakozásából eredő kötelezettségvállalásoknak. A Bíróság szerint ezzel a megállapodás korlátozza az előzetes bevonásra irányuló eljárás terjedelmét a másodlagos jog tekintetében, és ez sérti az Unió és a Bíróság hatásköreit.

2.7. Végül hetedikként a Bíróság az uniós jognak a közös kül- és biztonságpolitika (a továbbiakban: KKBP) területén végzett bírósági felülvizsgálat tekintetében fennálló szabályait értelmezte a megállapodással összefüggésben. A Szerződések rendszerében a KKBP különös rendelkezések hatálya alá tartozik. A Bíróság fö szabályként nem rendelkezik hatáskörrel a KKBP-ra vonatkozó rendelkezések, valamint az azok alapján elfogadott jogi aktusok tekintetében. Létezik azonban két kivétel. Egyrészt az EUSZ 40. cikkének ${ }^{53}$ betartását a Bíróság adott esetben ellenőrizheti, másrészt van hatásköre a Tanács által a KKBP-ra vonatkozó különös rendelkezések alapján a természetes vagy jogi személyekre vonatkozóan elfogadott korlátozó intézkedéseket előíró határozatok jogszerüségének felülvizsgálatára irányuló megsemmisítés iránti keresetek elbírálására is. A Bíróság úgy vélte, hogy a csatlakozással az EJEB jogosult lenne arról határozni, hogy megfelelnek-e az EJEE-nek egyes, a KKBP keretében meghozott jogi aktusok, fellépések vagy mulasztások, beleértve azokat is, amelyek tekintetében a Bíróság nem rendelkezik hatáskörrel azok jogszerűségének felülvizsgálatára. A gyakorlatban ez azt jelentené, hogy egy Unión kívüli szervre, az EJEB-re lenne bízva ezen döntések - az EJEE-ben biztosított jogok tiszteletben tartására korlátozódó - bírósági felülvizsgálata. A Bíróság egy korábbi döntését idézte ezzel összefüggésben, amelyben már megállapította azt, hogy az ilyen hatáskör nem ruházható át kizárólagosan egy olyan nemzetközi bíróságra, amely az Unió intézményi és igazságszolgáltatási keretén kívül helyezkedik el. ${ }^{54}$ A Bíróság szerint ezért a tervezett megállapodás nincs tekintettel az uniós jog bírósági felülvizsgálata tekintetében a KKBP területén fennálló sajátos jellemzökre.

\section{Kritikai észrevételek}

3.1. A Bíróság első kifogása az EJEE és a Charta egyes szakaszai közötti állítólagos ellentmondásra vonatkozott. Mindjárt az elején szükségesnek tartjuk rögzíteni, hogy nem tartjuk kellően érthetőnek, és ebből következően meggyőzőnek, a Bíró-

52 Lásd a magyarázó jelentés tervezetének 66. pontját.

53 „A közös kül- és biztonságpolitika végrehajtása nem sérti az Európai Unió müködéséröl szóló szerződés 3-6. cikkében felsorolt uniós hatáskörök gyakorlására vonatkozóan a Szerződésekben az intézmények részére elöírt eljárások alkalmazását és az intézmények erre vonatkozó hatásköreinek terjedelmét. Hasonlóképpen, az e cikkekben felsorolt politikák végrehajtása nem sérti az Unió e fejezetben említett hatásköreinek gyakorlására vonatkozóan a Szerződésekben az intézmények részére előirt eljárások alkalmazását és az intézmények vonatkozó hatásköreinek terjedelmét”. (EUSZ 40. cikk)

54 Lásd a Bíróság 1/09. számú véleményének (ECLI:EU:C:2011:123) 78., 80. és 89. pontjait. 
ság ezzel kapcsolatos érveit. Nem világos számunkra, hogy miben is áll pontosan az EJEE 53. cikke és a Charta 53. cikke közötti kollízió. ${ }^{55}$ Mindkét cikk arról szól ugyanis, hogy a szerződő felek/a tagállamok az EJEE-ben/a Chartában biztosítottnál magasabb védelmi szintet is előírhatnak az alapvető jogok terén. ${ }^{56}$ Miért is kellene két, tartalmilag megegyező rendelkezés között „összhangot” teremteni? A Bíróság indokolását ${ }^{57}$ pedig különösen érthetetlennek találjuk, amikor részben az EJEE-ben rögzítetthez képest magasabb védelmi szintre vonatkozó tagállami diszkréció korlátozásában véli megtalálni a probléma lehetséges megoldását. ${ }^{58}$

A bírák szerint tehát korlátozni kellene a tagállamoknak azt a lehetőségét, hogy az olyan alapvető jogok esetén - amelyeket a Charta is biztosít, és tartalmilag megfelelnek az EJEE-ben biztosított jogoknak - magasabb védelmi szintet írhassanak elö, mint amit az EJEE biztosít. Hiányoljuk a Bíróság részletes érveit és magyarázatát ahhoz a megállapításhoz, amely szerint ennek hiányában veszélyeztetve lenne az uniós jog elsőbbsége, egységessége és hatékonysága akkor, amikor ugyanezt a lehetőséget a Charta is biztosítja valamennyi tagállam számára.

3.2. A tagállamok közötti kölcsönös bizalom elvével összefüggő megállapítások és azok indokolása sem tűnik kellően megalapozottnak számunkra. Úgy gondoljuk, hogy a Bíróság hibás következtetésre jutott akkor, amikor ellentmondást fedezett fel abban, hogy miközben az uniós jog a kölcsönös bizalmat írja elő a tagállamok között, addig az EJEE megkövetelné a tagállamoktól, hogy adott esetben vizsgálják meg az alapvető jogok más tagállam általi tiszteletben tartását. Nem vitatjuk azt, hogy az uniós jog egyes tételes rendelkezései valóban arra kötelezik a tagállamokat, hogy bízzanak a többi tagállam alapjogvédelmi rendszerében. Ebből a szempontból valóban problematikus lehetne, ha a tagállamok a kölcsönös bizalomtól eltérő magatartást tanúsítanának a csatlakozást követően.

A Bíróság azonban indokolása során figyelmen kívül hagyott egy olyan eljárást, amelynek létezése álláspontunk szerint önmagában is cáfolja a véleménynek a tagállamok közötti kölcsönös bizalom elvével összefüggésben tett megállapításait. Az Amszterdami Szerződés által beiktatott EUSZ 7. cikk ugyanis ilyen tartalmú javaslat alapján egyenesen az Európai Tanács, illetve a Tanács - azaz a többi tagállam - kötelezettségévé teszi annak vizsgálatát és esetleges megállapítását, hogy egy tagállam súlyosan és tartósan megsérti-e az EUSZ 2. cikkét, vagy fennáll-e az egyértelmű veszélye annak. Egy ilyen döntés szükségszerüen feltételezné, hogy a tag-

${ }_{55}$ A Charta 53. cikkének értelmezéséhez lásd a C-399/11. számú, Melloni-ügyben hozott ítélet (ECLI:EU:C:2013:107) 55-64. pontjait.

${ }^{56}$ Ehhez lásd még Finck, Michéle: The Court of Justice of the European Union Strikes Down EU Accession to the European Convention on Human Rights: What Does the Decision Mean? http://www.iconnectblog.com/2014/12/the-court-of-justice-of-the-european-union-strikes-down-eu-accession-to-the-europeanconvention-on-human-rights-what-does-the-decision-mean/ (2015. 02. 09.) és Douglas-ScotT, Sionaidh: Opinion 2/13 on EU accession to the ECHR: a Christmas bombshell from the European Court of Justice. http://www.verfassungsblog.de/en/opinion-213-eu-accession-echr-christmas-bombshell-european-courtjustice/\#.VNh3s-85Cwk (2015. 02. 09.).

57 Lásd a 2.1. alpont utolsó mondatát.

58 Lásd a vélemény 189 . pontját. 
államok adott esetben vizsgálják meg egyebek mellett az alapvető jogok más tagállam általi tiszteletben tartását is. Tény, hogy ezt az ún. nukleáris klauzulát még soha nem alkalmazták és politikailag rendkívül csekély az esélye annak, hogy valaha is müködésbe hozzák. Ennek ellenére sem lehet figyelmen kívül hagyni a lehetőségét. Ezért úgy gondoljuk, hogy a Bíróságnak, mielőtt a fenti következtetésre jutott volna, az indokolásban meg kellett volna ezt vizsgálnia és esetleg magyarázatot keresni arra, hogy az EUSZ 7. cikk és a kölcsönös bizalom elve milyen viszonyban vannak egymással. Ez azért is lett volna hasznos, mert amennyiben a Bíróság arra a következtetésre jutott volna, hogy a jelenlegi uniós jogban is vannak rendelkezések, ${ }^{59}$ amelyek kivételt képeznek a kölcsönös bizalom elve alól, akkor ugyanezt megállapíthatta volna analógia útján az EJEE-vel kapcsolatban is.

3.3. Ami az EJEE-hez csatolt 16. jegyzökönyvvel foglalkozó harmadik kifogást illeti, véleményünk szerint a Bíróságot ennél a következtetésnél, és különösen annak indokolásában elsősorban saját hatásköre megóvásának szándéka vezette. A Bíróság ebben nem tartotta egymással összeegyeztethetőnek az EJEB tanácsadó vélemény iránti eljárását a saját előzetes döntéshozatali eljárásával. Az indokolása azonban nem tünik kellően meggyőzőnek számunkra. A Bíróság okfejtéséből kimondatlanul az következik, hogy mivel a csatlakozással az EJEE az uniós jog szerves része lenne, az uniós jog értelmezésére hivatott előzetes döntéshozatali eljárásba tartoznának az EJEE biztosított jogok értelmezésével kapcsolatos, tagállami bíróságtól érkező kérelmek is. A vélemény adós maradt azzal is, hogy - ellentétben néhány másik kifogással - megjelölje azt, hogyan kellene megváltoztatni a megállapodást ahhoz, hogy az - a Bíróság értelmezésében - már ne sértse meg az előzetes döntéshozatali eljárás hatékonyságát és autonómiáját.

3.4. Ami az EUMSZ 344. cikkének megsértését részletező negyedik pontot illeti, úgy gondoljuk, hogy a Bíróság érvei közül ez tűnik az egyik leginkább megalapozottnak, és legkevésbé vitathatónak. Mindazonáltal e megállapításunkat csak akkor tartjuk indokoltnak, ha a "Szerződések” fogalmába - a Bíróság kiterjesztő értelmezését magunkévá téve - beleértjük a csatlakozás után az EJEE-t is. Kétségkívül igaz ugyan, hogy a csatlakozással az EJEE az uniós jog szerves részévé válna, de kérdés, hogy az EUMSZ 344. cikkének alkotói az Unió által kötött nemzetközi egyezmények értelmezésére és alkalmazására vonatkozó vitáik tekintetében is ki akarták-e zárni a Szerződéseken kívüli eljárásokat. A véleményben javasolt megoldásnak mindenesetre nem látjuk technikai akadályát.

3.5. Az alperesi pertársaság mechanizmusával összefüggően több megállapítást is tett a Bíróság. Úgy véljük, hogy a Bíróságnak mindhárom kifogása logikusnak és védhetőnek tűnik. Ezek közül az első csak úgy lenne feloldható, ha a megállapodás felülvizsgálatakor vagy kizárnák annak a lehetőségét, hogy az Unió, illetve

${ }^{59}$ Az EUMSZ 259. cikk szerinti tagállami kötelezettségszegés megállapítása iránti eljárásról akkor még nem is tettünk említést, amely szintén árnyalja a kölcsönös bizalom elvének értelmezését. 
egy tagállama saját kérelmére alperesi pertárssá váljon, vagy az alperesi pertárssá válásukhoz elegendő lenne az ilyen tárgyú egyoldalú nyilatkozatuk, kizárva az EJEB mérlegelési lehetöségét.

3.6. Ami a Bíróság előzetes bevonására irányuló eljárásra vonatkozó következtetéseket illeti, magunk a két kifogás közül az elsőt tartjuk megalapozottabbnak, amely a megállapodás kisebb korrekciójával részben rendezhetőnek tűnik. Ehhez szükség lenne a Bíróság szerint az EJEB jogkörének elvi kizárására, és az uniós intézmények szóban forgó döntésének EJEB általi tiszteletben tartási kötelezettségének kimondására. Ehhez képest kevésbé pontosan meghatározhatónak véljük a Bíróságnak azon elvárását az eljárás kialakítására vonatkozóan, hogy az EJEB előtti minden folyamatban lévő ügyben valamennyi megfelelő információt megkapjon az Unió, illetve az uniós intézmények a fenti döntésükhöz.

Ami a második kifogást illeti, az meglehetősen erőltetettnek, sőt kifejezetten hibásnak tủnik, hiszen a Bíróság nem a megállapodással vitatkozik, hanem a magyarázó jelentés tervezetével, amelyek nyilvánvalóan nem tekinthetők egymással azonos joghatással bíró dokumentumoknak. Álláspontunk szerint a Bíróság tévesen állapította meg, hogy a megállapodás kizárja a másodlagos jog értelmezésére vonatkozó kérdéseket az előzetes bevonásra irányuló eljárásban. A Bíróságnak össze kellett volna vetnie a megállapodást és az ahhoz kapcsolódó magyarázó jelentés tervezetét, és adott esetben meg kellett volna állapítania, hogy a kettő nem koherens egymással. A magyarázó jelentés nyilvánvalóan nem változtathatja meg a megállapodás eredeti értelmét. Esetünkben „a rendelkezés összeegyeztethetöségének vizsgálata" kifejezésbe a nyelvtani és minden más értelmezési módszer szerint is bele kell tartoznia az adott jogi aktus értelmezésére vonatkozó döntésnek is. A Bíróság azonban ennek megállapítása helyett, a megállapodás föszövegével ellentétes tartalmú és kötelező joghatással egyébként sem bíró magyarázó jelentésre alapozta a következtetését.

3.7. A Bíróságnak az utolsó, KKBP-vel kapcsolatos kifogását több szempontból sem tartjuk megalapozottnak. Talán nem véletlen egybeesés, hogy a Common Market Law Review (CMLR) szerkesztője is ezt tekinti a Bíróság kifogásai közül a legproblematikusabbnak. ${ }^{60}$ Mindjárt az első kritikai észrevételünk az, hogy a vélemény az összes problémásnak minősített terület közül ezt indokolja meg a legrövidebben és legkevésbé meggyőzően. Továbbá a Bíróság ebben a feltűnően szűkszavú indokolásban is súlyos önellentmondásba keveredett, hiszen maga is elismerte, hogy az általa vázolt helyzet nem a megállapodásnak, hanem a Bíróság - uniós jog által szabályozott - hatásköri rendszerének a következménye. Másfelöl a véleményben idézett korábbi ügyben született döntés nem teljesen hasonlítható össze az Unió EJEE-hez való csatlakozásának az ügyével. ${ }^{61}$ Harmadrészt szembetűnő, hogy - el-

60 "The EU's Accession to the ECHR - a »NO« from the ECJ!", Editorial comments, Common Market Law Review (52) 2015, 12.

61 A vélemény az „Európai és közösségi szabadalmi bíróság” létrehozásáról szóló megállapodás tervezetéröl állapította meg annak az uniós joggal való összeegyeztethetetlenségét. 
lentétben a véleményben felhozott egyes más kifogásokkal - a Bíróság ebben az esetben még javaslatot sem tesz arra, hogy miben kellene módosítani vagy kiegészíteni a megállapodást ahhoz, hogy arra maga is „rábólintson”. ${ }^{62}$

Mindent összevetve a Bíróság nem adott számunkra elfogadható indokolást és magyarázatot arra, hogy az EJEB-nek - az EJEE-ben biztosított jogok tiszteletben tartására korlátozódó - felülvizsgálati hatásköre a KKBP területén mennyiben érintené a Bíróság hatásköreit. Álláspontunk szerint ennél a pontnál érződik leginkább a véleményen az, hogy mintha a Bíróságot egyfajta "hatásköri féltékenység” vezette volna, mondván, ha neki fö szabályként nincs joga a KKBP területén a felülvizsgálatra, akkor ne legyen más bíróságnak se, föleg Strasbourgnak ne. Ezzel szemben megközelíthette volna a Bíróság úgy is ezt az új helyzetet, amely nem sérti, hanem éppen kiegészítheti a felülvizsgálati lehetöségeket a KKBP területén, de csak korlátozott és az EJEE-hez közvetlenül kapcsolódó területeken. ${ }^{63} \mathrm{~A}$ CMLR ehhez kapcsolódóan felhívja a figyelmet arra, hogy mivel az Unió EJEE-hez való csatlakozásának kötelezettsége a Lisszaboni Szerződésböl fakad, annak megalkotói, azaz a tagállamok, nyilvánvalóan semmilyen ellentmondást nem láttak a Bíróságnak a KKBP területén az uniós jog által szabályozott korlátozott hatásköre és az EJEB hatáskörének ugyanezen téren való elismerése között. ${ }^{64}$

\section{Hogyan tovább?}

A Bíróság véleménye azt jelenti, hogy a megállapodás csak akkor léphet hatályba, ha azt módosítják, vagy a Szerződéseket felülvizsgálják. Tekintettel arra, hogy az EUSZ alapján az Uniónak kötelezettsége az EJEE-hez való csatlakozás, ezért az uniós intézményeknek újra kell kezdeniük a tárgyalásokat a csatlakozási megállapodásról. Ennek jövőbeli kimenetele azonban fölöttébb kétséges. A Bíróság által megfogalmazott kifogások között vannak olyanok, amelyek viszonylag könnyen rendezhetőnek és megoldhatónak tünnek (lásd például a negyedik és ötödik kifogást). Más pontot illetően (lásd például az első kifogást) nem teljesen világos számunkra, hogy mit várna el a Bíróság a megállapodás felülvizsgálata során.

Jogtechnikai szempontból azonban nem tűnik feloldhatónak a csatlakozási tárgyalások során a Bíróság hetedik kifogása. Az EJEE értelmében ugyanis a fenntartásoknak csak az egyezmény egyedi rendelkezéseivel szemben van helye, viszont „általános jellegü fenntartásokat nem lehet tenni”. ${ }^{55}$ Az EJEB hatáskörének kizárása

62 Varju szerint itt jön ki az az ellentmondás a véleményben, hogy a csatlakozás célja az uniós jogrend megváltoztatása volt, és a Bíróság szerint a csatlakozás azért nem történhet meg, mert megváltoztatná az uniós jogrendet. Lásd: http://jog.tk.mta.hu/blog/2015/02/kulon-marad-ami-osszetartozik (2015. 03. 04.).

63 Ugyanerre a következtetésre jut a CMLR is, amely szerint az EJEB joghatóságának az elismerése a KKBPvel kapcsolatos ügyekben megerősíthetné a személyek jogvédelmét a jelenlegi helyzethez képest [,The EU's Accession to the ECHR - a »NO« from the ECJ!", Editorial comments, Common Market Law Review (52) 2015, 13.].

64 "The EU's Accession to the ECHR - a »NO« from the ECJ!", Editorial comments, Common Market Law Review (52) 2015, 13.

65 EJEE 57. cikk 1. 
a KKBP keretében meghozott jogi aktusok, fellépések vagy mulasztások jogszerüségének felülvizsgálata során azonban tartalmilag ilyen általános jellegü fenntartás lenne. Tekintettel arra, hogy az EJEE e rendelkezésének módosítása gyakorlatilag kizárható, ezért az egyetlen megoldásnak - a Bíróság véleményét tiszteletben tartva - csak az tünik, ha az uniós jogot, azaz a Szerződéseket módosítják annak érdekében, hogy a Bíróság számára biztosított legyen a KKBP területén az általános felülvizsgálat lehetősége. Ahogy a CMLR is megjegyzi, erősen kérdéses, hogy a tagállamok egyáltalán támogatnának-e egyhangúan egy ilyen tartalmú felülvizsgálatot, és egy esetleges szerződésmódosítás egyébként sem tűnik rövid távon reálisnak és politikailag kivitelezhetőnek, így „az Unió csatlakozása az EJEE-hez most egy lehetetlen küldetéssé vált". ${ }^{66}$ Amennyiben az EJEE-hez való Uniós csatlakozás végképp kivitelezhetetlenné válik, akkor felmerülhet a Szerződések esetleges módosítása is, a feltételes mód használatával, hogy tudniillik az „Unió csatlakozhat” az EJEE-hez, amivel lehetőséggé változna a jelenlegi kötelezettség, ugyanakkor továbbra is demonstrálná az Uniónak az emberi jogok és alapvető szabadságjogok védelme iránti elhivatottságát.

Úgy gondoljuk, hogy a Bíróság döntése egyfajta „pozícióharcra” enged következtetni, amelyet Luxembourg folytat Strasbourggal szemben, annak érdekében, hogy megakadályozza az ítélkezési privilégiumának - az EJEE-hez való csatlakozással elkerülhetetlen - csorbítását. Ez meglehetősen új fejlemény a kapcsolatukban, mivel a két nemzetközi bíróság történetére alapvetően az együttműködés a jellemző, bár számos példát találhatunk arra is, hogy eltérően értelmeztek bizonyos alapvető jogokat. ${ }^{67} \mathrm{~A}$ „küzdelem” azonban a jelenlegi szakaszban egyrészt meglehetősen egyoldalú, másrészt egyenlőtlen. Egyoldalú azért, mert a csatlakozással csak a Bíróságnak van „veszítenivalója”, így a csatlakozás időbeli elhalasztása, teljes megakadályozása vagy akár csak a jelentős módosítások kikényszerítése is, kizárólag neki áll „érdekében”, mivel azzal nem csorbulna a jelenlegi jogértelmezési monopóliuma. Másrészt egyenlőtlen is, mivel csak a Bíróságnak van joga felülvizsgálhatatlan és végső döntésével megakadályozni a csatlakozást, ezzel szemben az EJEB-nek nincs döntési joga, föleg nem vétójoga ebben a folyamatban.

Úgy gondoljuk, hogy a Bíróság rendkívül mereven ragaszkodott a saját hatásköreihez, és azokat még jogi szempontból erősen vitatható indokokkal is „megvédésre" érdemesnek tartotta az EJEB-bel szemben. Feltételezésünk szerint tehát a Bíróságot nem kizárólag jogi szempontok vezérelték; a több ponton is vitatható indokolás és jogi érvelés azt a benyomást kelti bennünk, mintha a luxembourgi bírák pozíciójuk védelmében fogalmazták volna meg az érveiket, mintha kizárólag a negatív tartalmú véleményre és az azt alátámasztani hivatott kifogások megfogalmazására irányultak volna erőfeszítéseik.

A CMLR szerint a Bíróságnak ez a rugalmatlan magatartása még súlyos következményekkel is járhat a jövőben, a Bíróság és a tagállami alkotmánybíróságok

66 „The EU's Accession to the ECHR - a »NO« from the ECJ!”, Editorial comments, Common Market Law Review (52) 2015, 14.

67 A versenyjog területéről lásd ehhez például: SzILÁGYı Pál: Rövid észrevételek egy véleményhez. A Bíróság 2/13. sz. véleményéhez füzött kritikai észrevételek, Pázmány Law Working Papers, 2015/2. 
viszonyára nézve. Utóbbiak ugyanis akár követésre érdemesnek találhatják azt a logikai gondolatmenetet, amellyel a Bíróság a saját hatásköreit félti és védi az EJEBtől. Adott esetben majd hasonló módon indokolhatják meg azt, hogy miért kell megvédeni a saját hatásköreiket immár a Bírósággal szemben, és nem zárható ki az sem, hogy az EJEE-hez csatolt tizenhatodik jegyzőkönyvhöz ${ }^{68}$ csatlakozott uniós tagállam bírósága esetleg mégis az - emberi jogok terén általa kompetensebbnek tekintett - EJEB-hez fordul majd a Bíróság helyett. ${ }^{69}$

Végül felmerül bennünk az a kérdés is, hogy a Bíróság döntését követően van-e, és ha igen, akkor milyen értelme a csatlakozásnak. Ennek igénye akkor merült fel elsőként, amikor az Uniónak még nem volt saját alapjogi dokumentuma. Mivel 2000 óta már létezik ilyen, 2009 decemberétöl pedig kötelező is, így felvethető, hogy talán nem is kellene „eröltetni” ezt az ügyet, mivel azt gondolhatnánk, hogy az Alapjogi Charta kötelező jogi erővel való felruházásával lényegében okafogyottá vált ez a kérdés. A szakirodalomban három fö érvet találunk az Unió csatlakozása mellett. ${ }^{70}$ Az első szerint a csatlakozás erősítené az egyének jogvédelmét, mivel olyan területeken - különösen a KKBP-vel kapcsolatos ügyekben - is megnyitná az EJEB általi bírósági felülvizsgálat lehetőségét, ahol arra az uniós jog jelenleg nem ad lehetöséget. A másik érv az emberi jogok védelme közös európai térségének létrehozásában látja a csatlakozás előnyét, amelyben a végső döntés joga az EJEB-et illetné meg ilyen kérdésekben, megakadályozva a hármas ítélkezési gyakorlat kialakulását. A harmadik szerint pedig szimbolikus üzenete is lenne annak, és erősíthetné az Unió törekvését világszerte az emberi jogok védelmének biztosítására irányuló eröfeszítéseiben, amennyiben az Unió is alávetné magát az EJEB által meghatározott emberi jogi követelményeknek, beleértve a külső kontrollt is. Mint az elemzésünk mutatta, a Bíróság számára azonban éppen ezek miatt nem fogadható el a csatlakozás. Ebből az következik, hogy abban a valószínütlen esetben, ha a megállapodás útjában álló valamennyi - Bíróság által megfogalmazott - jogi akadály elhárulna, akkor éppen a csatlakozás pozitívnak tekinthető hozadéka veszne el.

\section{Abstract}

The accession of the European Union (EU) to the European Convention on Human Rights (ECHR) has been on the agenda of the EU for long. Although the Lisbon Treaty settles this question in theory by obliging the EU to accede, the European Court of Justice (ECJ) resorted to its rights laid down in the Treaties and published its Opinion 2/13 on the matter by the full Court. This opinion scrutinizes the draft document concerning accession. According to the opinion the EU cannot accede to the ECHR in the present form because the draft document is not in compliance

68 Lásd a 2.3. alpontot.

69 „The EU's Accession to the ECHR - a »NO« from the ECJ!", Editorial comments, Common Market Law Review (52) 2015, 15.

70 Lásd ehhez KuIJER, Martin The Accession of the European Union to the ECHR: A Gift for the ECHR's $60^{\text {th }}$ Anniversary or an Unwelcome Intruder at the Party?, Amsterdam Law Forum (3) 2011., 20-21. 
with the special characteristics and features of EU law, therefore it would require the amendment or re-organisation of the whole EU legal system. By this judgement the ECJ outlines the legal impediments in the way of the accession. The main objective of our article - after summarizing the brief history and legal framework of the accession - is to present and evaluate the critical elements of accession determined by the ECJ and predict the decision's possible consequences. 